\title{
Independent Learning through Interactive Multimedia Based on Problem Based Learning
}

\author{
Zainul Arifin1*, I Made Tegeh², Adrianus I Wayan Ilia Yuda Sukmana ${ }^{3}$ \\ 1,2,3 Program Studi Teknologi Pendidikan, Universitas Pendidikan Ganesha, Singaraja, Indonesia
}

\section{ART I C L E I N F O}

Article history:

Received August 15, 2021

Revised August 20, 2021

Accepted November 11, 2021

Available online December 25, 2021

Kata Kunci:

Multimedia pembelajaran interaktif, ADDIE, PBL, Mandiri

Keywords:

Interactive Learning Multimedia, ADDIE, PBL, Independent

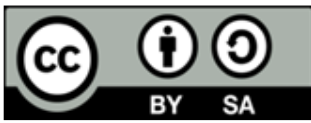

This is an open access article under the CC BY-SA license.

Copyright (@) 2021 by Author. Published by Universitas Pendidikan Ganesha.

\begin{abstract}
A B S T R A K
Penelitian ini didasari kurangnya penggunaan media pembelajaran yang kreatif dan interaktif. Hal ini berdampak pada hasil belajar peserta didik. Penelitian ini bertujuan untuk mendeskripsikan proses pengembangan multimedia pembelajaran interaktif. Penelitian pengembangan ini menggunakan model pengembangan ADDIE. Subjek penelitian pengembangan ini yaitu 1 ahli isi mata pelajaran, 1 ahli desain pembelajaran, 1 ahli media pembelajaran, 3 siswa untuk uji perorangan, dan 9 siswa untuk uji kelompok kecil. Metode pengumpulan data yang digunakan dalam penelitian pengembangan ini yaitu metode wawancara, metode observasi, dan metode kuesioner. Instrumen yang digunakan untuk mengumpulkan data yaitu kuesioner. Teknik yang digunakan untuk menganalisis data yaitu analisis deskriptif kualitatif dan kuantitatif. Hasil penelitian pengembangan ini multimedia pembelajaran interaktif ini dinyatakan valid dengan hasil review ahli isi mata pelajaran sebesar $98,46 \%$ dengan kualifikasi sangat baik. Hasil review ahli desain pembelajaran sebesar 92 \% dengan kualifikasi sangat baik. Hasil review ahli media pembelajaran sebesar 92,72\% dengan kualifikasi sangat baik. Hasil review dari uji perorangan sebesar 95\% dengan kualifikasi sangat baik. Hasil review dari uji kelompok kecil sebesar 95,17\% dengan kualifikasi sangat baik. Multimedia pembelajaran interaktif berbasis model pembelajaran problem-based learning (PBL) layak digunakan untuk proses pembelajaran.
\end{abstract}

\section{A B S T R A C T}

This research is based on the lack of use of creative and interactive learning media. This has an impact on student learning outcomes. This study aims to describe the process of developing interactive learning multimedia. This development research uses the ADDIE development model. The subjects of this development research are one subject matter expert, 1 learning design expert, 1 learning media expert, 3 students for individual testing, and 9 students for small group testing. The data collection methods used in this development research are the interview method, observation, and questionnaire method. The instrument used to collect data is a questionnaire. The technique used to analyze the data is descriptive qualitative and quantitative analysis. The results of this research on the development of interactive multimedia learning were declared valid with the results of expert reviews of the subject matter content of $98.46 \%$ with very good qualifications. The results of the learning design expert review are $92 \%$ with very good qualifications. The results of the learning media expert review are $92.72 \%$, with very good qualifications. The review results from the individual test are 95\%, with very good qualifications. The review results from the small group test were $95.17 \%$, with very good qualifications. Multimedia interactive learning based on the problem-based learning (PBL) model is suitable for learning.

\section{INTRODUCTION}

Education is a process of interaction between students and teachers in the form of learning information that contains education as a source of learning and media as a means of learning (Afriyanti et al., 2021; Dumitrescu et al., 2014; Zhang et al., 2020). For this reason, education is a conscious and planned effort aimed at creating a learning environment and learning process for students to actively develop their 
potential in the form of religious spirituality, noble character, personality, self-control, intelligence, and other (Abbas \& Sagsan, 2020; Johansson et al., 2020). The development of computer technology has a tremendous impact on learning today. One of them in the teaching and learning process, the teacher, must not only make the learning environment fun and interesting, but the teacher must also understand and master the knowledge of learning management inside and outside the classroom (Ghory \& Ghafory, 2021; Lynch et al., 2021). Teachers must also be able to integrate technology into learning, including through the use of learning media. The choice of a particular teaching method influences the appropriate instructional media, although other aspects must be considered when selecting instructional media (Agustiwan, 2021; Ružičić, 2021). It is because technological developments cannot maximize the teaching and learning process in the classroom. Therefore adequate learning methods are needed to take advantage of existing facilities (Fatqurhohman, 2021; Simamora, 2020). The learning process plays a critical role in producing or creating quality education graduates to create a quality learning process (Codreanu et al., 2020; Graham et al., 2020; Kaso et al., 2021).

However, today's problem is that there are still many teachers who have difficulty using technology to develop teaching materials or learning media that can facilitate students in learning (Simamora, 2020; S. S. Weng \& Chen, 2020). In addition, many cases are found regarding the implementation of classroom learning that is still centred on teachers who use the lecture method, which makes students bored in learning (Syauqi et al., 2020; Yuzulia, 2021). This problem was also found in one elementary school. Based on the results of observations and interviews conducted at SDN 1 Banjar Bali, it was found that the problem was that the fifth-grade teacher at SDN 1 Banjar Bali said that teachers had problems in learning, namely the lack of learning media used and the lack of facilities and infrastructure in schools that did not support the production of video media or audio. The teacher also has difficulty conveying the content, especially in relating the material and providing examples of temperature and heat descriptions, because the teacher only explains without pictures of changes in the shape of objects due to the lack of available media. Moreover, students also have difficulty digesting the material presented by the teacher. This condition will make it difficult for students to learn science subjects. Students will only know and study science material because of the limitations of the learning media used to increase students' knowledge during learning. In this case, the lack of innovation, creative and interactive learning tools in the classroom, and the lack of interaction between teachers and students so that interest in learning can be generated by the students themselves (Jogezai et al., 2021; Samsudin et al., 2019). In accordance with the minimum completeness criteria (KKM) set by the school, namely 63 with a class average of 69.6 and all students in class V/B totaling 32 students. There were 9 students who completed while 23 students did not complete. The problem with low student learning outcomes is that in this learning the teacher only relies on textbooks and visual media, so that students only know the contents of the material in the textbook and there is no application of multimedia learning that involves students' interest in learning.

The solution offered to overcome these problems is to develop interactive teaching materials. One of them that can be used is interactive multimedia learning using problem-based learning (PBL) learning models. Learning multimedia is media in the form of multimedia packages as a tool to display media content in text, images, audio and video or animation used in learning activities with the help of computer devices for operation (Prasetyo et al., 2020; Rubini et al., 2018). Currently, multimedia refers to the fusion and integration of media such as text, animation, graphics, sound and video in a computer system (Calista \& Pujiriyanto, 2021; Fauyan, 2019).

In this case, it defines multimedia as the use of various forms of media in presentations (Lauc et al., 2020; Ngurah et al., 2019). Multimedia that is very well known today combines graphics, text, sound, video, and animation. This association is a unit that displays information, messages or learning content together. Various combinations of graphics, text, sound, video and animation are multimedia (Prasetyo et al., 2020; Purwanita et al., 2019). The components in multimedia can be divided into five parts: text, images, sound, animation, and video (Prasetyo et al., 2020; Purwanita et al., 2019). In addition to the importance of interactive multimedia learning, learning also requires the selection and application of learning models. The learning model is a plan or pattern that we can use to design a lesson that will be used in the classroom. One of the learning models that can support interactive multimedia in the learning process is the problem-based learning (PBL) model.

The problem-based learning (PBL) learning model is a learning model in which students solve a problem through the stages of the scientific method so that they learn knowledge related to the problem and have the skills to solve problems (Kavanagh et al., 2020; Ngalimun, 2016). It can be concluded that the problem-based learning (PBL) learning model is an educational approach where the problem is the starting point of the learning process (Hussin et al., 2018; Kristinawati et al., 2018). Various learning processes are needed to acquire knowledge and skills, along with each individual's ability to apply them to life applications. The problems presented are contextual problems with the real world, stimulating students to 
think actively and critically according to their experiences (Kumala et al., 2020; Suryawati \& Osman, 2018). The main goal of problem-based learning (PBL) is not only to provide a large amount of knowledge to students but also to develop critical thinking skills, learn authentic adult roles and students' ability to actively build their knowledge (Hotimah, 2020; Nurtanto et al., 2020). This Suparwati arises when students try to solve existing problems with their skills. With this habituation, students can understand the material more deeply.

The findings of previous research also stated differences in learning outcomes in Hindu religious lessons before using Hindu religious learning multimedia (Ayu et al., 2015). Other research findings also state differences in English learning outcomes before using English language learning multimedia (bin Abdul Samat \& Abdul Aziz, 2020). Other research findings also state that the results of this PBL interactive multimedia meet the criteria of validity in learning and practicality in learning (Khamzawi \& Wiyono, 2015). Other findings also state significant differences in science learning outcomes between students who learn to follow the conventional learning model in fifth-grade elementary school (Kristiana \& Radia, 2021; Lestari, 2019). So based on these findings, it can be concluded that interactive learning multimedia is proven to impact student learning outcomes positively.

\section{METHOD}

This type of research is development research. This development research was carried out at SD Negeri 1 Banjar Bali in class V. The procedure for this development research used refers to the ADDIE development model, which consists of five stages, namely: the analysis stage; the design stage (design); development stage (development); implementation phase (implementation); and the evaluation stage (Cahyadi, 2019). The subjects of this development research are 1 subject matter expert, 1 learning design expert, 1 learning media expert, 3 students for individual trials, and 9 students for small group trials. Data collection methods used in this development research are observation method, interview method, and questionnaire method. This development research uses several instruments in collecting data for research, including observation sheets, interview sheets, and questionnaire sheets. This observation sheet is used to find out the facilities in learning owned by the school and students and to see the teaching and learning process that occurs in the classroom. The use of interviews in this study is to collect data by asking orally to obtain information from respondents. This guide is used to collect data regarding learning problems that occur in the field. Moreover, the use of a questionnaire or lift in this research collects data from reviews from content experts in the field of study or subjects, learning design experts and learning media experts, individual trials, and small groups. The instrument grid of subject matter experts, design experts, instructional media experts and individual trials can be presented in Tables 1, 2 and 3.

Table 1. Grid of Subject Content Expert Instruments

\begin{tabular}{lllc}
\hline No & Aspect & \multicolumn{1}{c}{ Indicator } & No \\
\hline 1 & Curriculum & The suitability of the material with core competencies & 1 \\
& & The suitability of the material with basic competencies & 2 \\
& & The suitability of the material with the indicators & 3 \\
2 & \multirow{3}{*}{ Method } & Completeness of the material presented & 4 \\
& & Accuracy of presentation of material in multimedia & 5 \\
& & The suitability of the example with the material presented & 6 \\
& & The suitability of the image in the multimedia with the material & 7 \\
& & The suitability of animation in multimedia with the material & 8 \\
4 & Language & Presentation of material can motivate students & 9 \\
& Evaluation & Suitability of language use in multimedia & 10 \\
& & Suitability of questions with learning objectives & 11 \\
& & The suitability of the question with the material & 12 \\
\hline
\end{tabular}

Table 2. Learning Design Instrument Grid

\begin{tabular}{cllc}
\hline No & \multicolumn{1}{c}{ Aspect } & \multicolumn{1}{c}{ Indicator } & No \\
\hline 1 & Theme & The suitability of the material with the learning objectives & 1 \\
& Accuracy & The suitability of the material with the chosen theme & 2 \\
2 & Methodology & Clarity of the description of the material presented with the theme & 3 \\
& (how to present & Clarity of learning methods & 4 \\
& the material) & The presentation of the material presented varies & 5 \\
\hline
\end{tabular}




\begin{tabular}{cclc}
\hline No & \multicolumn{1}{c}{ Aspect } & \multicolumn{1}{c}{ Indicator } & No \\
\hline 3 & Appearance & Terms of use of color & 6 \\
& & Terms of use of font size & 7 \\
& & Button and image layout constancy & 8 \\
4 & Interactivity & Attract learning motivation & 9 \\
& & Relevance of the question to the material & 10 \\
5 & Question & Easy to understand question & 11 \\
& quality & Question difficulty level & 12 \\
6 & Method & Appropriateness of apperception/illustration is presented in the & 13 \\
& & form of orientation to students' real problems & 14 \\
& & Clarity of included cases/events & 15 \\
\hline
\end{tabular}

Table 3. Learning Media Instruments Grid

\begin{tabular}{|c|c|c|c|}
\hline No & Aspect & Indicator & No. \\
\hline \multirow[t]{7}{*}{1} & Appearance & Attractive cover/cover design & 1 \\
\hline & & The suitability of the cover to the content / content in the multimedia & 2 \\
\hline & & Composition and color combinations that are right and match & 3 \\
\hline & & Quality of images, graphics, symbols and icons & 4 \\
\hline & & Readability of material in multimedia & 5 \\
\hline & & Button consistency in multimedia & 6 \\
\hline & & Media strength/durability & 7 \\
\hline \multirow[t]{3}{*}{2} & Programming & Consistent multimedia appearance & 8 \\
\hline & & $\begin{array}{l}\text { The linkage of the relationship between multimedia pages with other } \\
\text { pages }\end{array}$ & 9 \\
\hline & & Proper use of animation & 10 \\
\hline 3 & Curriculum & Multimedia learning contains elements of learning. & 11 \\
\hline
\end{tabular}

The data analysis method used in this interactive learning multimedia development research is a qualitative descriptive analysis method and a quantitative descriptive analysis method. This descriptive analysis method is used in processing data in the form of input, criticism, and suggestions in the questionnaire used in revising interactive learning multimedia products from the results of subject matter expert trials, learning design expert tests, learning media expert tests, individual test subjects and test subjects. Try small groups. At the same time, the quantitative descriptive data analysis method is a way of the data processing done by systematically compiling in the form of numbers and percentages regarding an object under study to obtain general conclusions (Agung, 2014).

\section{RESULTS AND DISCUSSION}

\section{Results}

The first stage is the analysis stage. At this stage, three things are analyzed, namely the analysis of student characteristics and problems in learning. Fundamental competency analysis (KD), namely applying the concept of heat transfer in daily life and indicators that include, among others: explaining the meaning of heat transfer, understanding the types of heat transfer and identifying ways of heat transfer in everyday life; facility/environment analysis. This stage of analysis was carried out through observation and interviews. The results of the analysis of student characteristics and problems in teacher learning are the primary learning resources in the classroom, with the method often used being the lecture method and the media used is audio-visual. In this case, students often feel bored and lack the motivation to learn. Then the fundamental competency analysis (KD) and indicators show that the instructional analysis carried out is related to the competencies required to be achieved by students. The material in the interactive learning multimedia developed is based on essential competencies (KD) and indicators. The facility/environment analysis results were carried out, namely to find out the infrastructure owned by the school, such as LCDs and computers. Based on the three analyzes in the analysis phase, the researcher developed an interactive multimedia learning model based on problem-based learning (PBL) in science subjects for fifth-grade elementary school. The second stage is the design stage. This stage is carried out, namely selecting and determining the software/software used to create interactive learning multimedia. The software used is Adobe Flash Professional CS6, Adobe Illustrator 2021, Adobe Audition CC 2017, Corel Draw X8, and 
Wondershire Filmora X; designing interactive learning multimedia flowcharts and storyboards; develop an interactive learning multimedia assessment instrument; compiling RPP (learning implementation plan). The third stage is the development stage. This stage is developing a product design made into a natural product based on flowcharts and storyboards, which will later be tested for feasibility in the field. The fourth stage is the implementation stage. The results of the development of interactive learning multimedia are presented ini Figure 1.
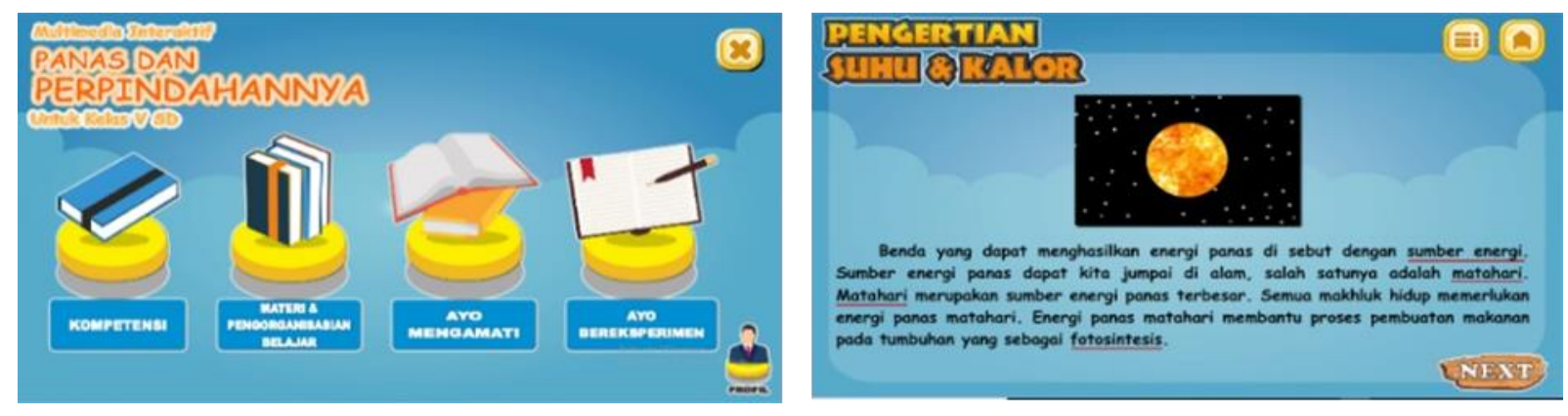

Figure 1. Multimedia Interactive Learning Problem Based Learning (PBL) Learning Model

At the implementation stage, the activities carried out are product validity tests by experts, including subject content experts, learning design experts, and learning media experts; product trials include individual and small group trials. The purpose of testing the validity of the product and testing the product is the effectiveness of the product and the feasibility of the product being developed. The final stage is the evaluation stage. The evaluation stage is the stage for revising the product according to the input, suggestions, and comments received after the feasibility test is carried out to students. Based on the validity test results of interactive learning multimedia products conducted by subject content experts, the percentage was $98.46 \%$, with very good qualifications. Learning design experts obtained a percentage of $92 \%$, with very good qualifications. Learning media experts obtained a percentage of $92.72 \%$, with very good qualifications. Individual trials get a percentage of $95 \%$, with very good qualifications. Small group trials get a percentage of $95.17 \%$ with very good qualifications. With very good validity, the product developed is feasible to be applied to the learning process in science lessons. Through the results of the validity of interactive learning multimedia products, suggestions, input, and comments will then be used as a reference for consideration to revise the product for the perfection of the developed interactive learning multimedia product.

\section{Discussion}

Based on further studies, several essential experts influence the validity of the developed interactive learning multimedia. The acquisition of very good validity qualifications for subject matter experts is influenced by the presentation of material by the demands of core competencies, essential competencies, and learning objectives used. The suitability of the media will determine the qualifications obtained (Kartika et al., 2019; C. Weng et al., 2018). The assessment results are evidence by subject matter experts on the instrument items related to the suitability of the material with core competencies, essential competencies, and learning objectives to obtain very good criteria. So it can be concluded that the suitability of content with learning objectives is essential in making media. In assessing content aspects, it is necessary to pay attention to the design of learning objectives, competencies and indicators (Lai et al., 2019; Ran \& Jinglu, 2020; Septia et al., 2018). Previous research findings stated that subject matter is an essential part of the learning process, even in the subject-centred teaching process, where the subject matter is the core of learning activities (Chen \& Li, 2011; Haddock et al., 2020). Other research findings also state that learning effectiveness is defined as realising learning outcomes by predetermined learning objectives (Shea et al., 2013). Clear goals can be used as a reference in every learning process (Arif, 2018; Astra et al., 2020). Based on the assessment of subject matter experts, it can be said that the interactive learning multimedia that has been developed is suitable for use by students in learning activities.

Very good qualifications for learning design experts were also obtained because the suitability of the presentation of the material could increase students' motivation, as well as the clarity of the media with the material presented. The suitability of learning materials will increase students' enthusiasm for learning (Garbin et al., 2020; Liang et al., 2011; Oh, 2019). The previous research findings stated that the media used in learning attract students and can motivate student learning (Alexander et al., 2020; Suartama, 2016). so that it makes the interactive learning multimedia developed easy to understand by students and increases student learning motivation, and can increase student interest in learning so that in the learning process, 
students can improve learning outcomes well (Lauc et al., 2020; Lee \& Osman, 2012). Other research findings also state that instructional design relates to determining learning objectives, strategies, and techniques to achieve learning objectives and providing examples or illustrations in the material (Febrita \& Harni, 2020; Sanjaya, 2015). Clarity of illustrations/examples of events in the form of problem orientation. In the development of interactive learning multimedia, it contains illustrations or examples of events in everyday life that are on a problem-oriented display, and each material is also presented with illustrations or examples of events in everyday life (Abu-Eisheh \& Ghanim, 2021). With these illustrations/examples, students can activate interest in learning, and students can also involve students to solve a problem in everyday life (Indah Septiani et al., 2020). Other research findings also state that problem-based learning can help students develop thinking and problem-solving skills and become independent learners (Chounta et al., 2017). Based on the assessment results that the learning design expert has given, it can be concluded that the interactive learning multimedia that has been developed is suitable for use by students in learning activities, especially in science subjects for class $V$ and can increase student learning motivation.

The interactive learning multimedia that has been developed pay attention to the elements of the determination and readability of the material in the multimedia, such as font size, typeface, writing space, the suitability of the layout of the text presented in interactive learning multimedia using sentences that are easy to read by students. Learning media has a crucial function, namely as carriers of information and preventing obstacles to the learning process, so that information or messages from communicators can reach the communicant effectively and efficiently (Lynch et al., 2021; Suartama, 2016). Quality of images, graphics, symbols and icons and consistency of multimedia appearance. In the interactive learning multimedia that has been developed, some pictures strengthen the delivery of the material. It is considered in the addition of pictures, among others, as follows; the quality of images, graphics, symbols and icons in the media; consistency of multimedia appearance (Bus et al., 2020; Marnita \& Ernawati, 2017). The presence of images, graphics, symbols and icons that match the material and the consistent multimedia appearance presented can attract students' attention to make learning fun (Khamparia \& Pandey, 2017; Khan \& Masood, 2015).

The media aspect is to determine the criteria for multimedia quality, which can generate motivation using images, graphics, symbols and icons and the consistency of the suitable multimedia appearance (Antal et al., 2017; Suartama, 2016). As with other research findings, it is also stated that long and abstract descriptions are easier to understand if visualized with pictures, and pictures can make it easier for people to remember messages (Kurniawan et al., 2020). The suitability of the cover to the content in the multimedia. In the development of interactive learning multimedia that has been developed, there is a cover in the multimedia. So that it can cause students' attention and can make it easier for students to understand the material presented on this multimedia. Quality criteria for learning multimedia such as covers will attract students' attention, leading to increased learning outcomes (Müller \& Wulf, 2020; Suartama, 2016). Materials that are facts and concepts require media so that students can easily understand the material (Imamah \& Susanti, 2021). The existence of interactive learning multimedia developed by researchers makes it easier for students to understand science learning. In addition, interactive multimedia learning is also interesting for students. That way, students become motivated to learn and improve learning outcomes (Dede Mukti Herdiyanto, Sulton, 2020; Utama et al., 2014).

Based on the results of this study, it has several implications, namely an interactive learning multimedia product based on problem-based learning (PBL) learning model with excellent qualifications so that students can understand learning materials, especially science. With interactive multimedia learning based on problem-based learning (PBL) learning models, teachers will find it easier to deliver learning materials and motivate teachers to create creative, innovative, and interactive learning media. In addition, the advantages of interactive learning multimedia products based on the problem-based learning (PBL) learning model developed are displaying concise media and interactive learning multimedia equipped with essential competencies, indicators, and learning objectives. In addition, interactive multimedia learning is also equipped with a problem orientation, which shows the problems found in the home and school environment. Moreover, this interactive learning multimedia is also equipped with independent observation/investigation. This interactive multimedia learning also reflects the problem-based learning (PBL) learning model. As well as this interactive learning multimedia, it is also equipped with learning videos to support the material being studied. However, there are shortcomings in developing interactive learning multimedia products based on problem-based learning (PBL) learning models. Namely, interactive learning multimedia products have not been implemented, so it is recommended that researchers continue this research and produce interactive learning multimedia products based on problem-based learning models. (PBL) on other learning materials and models. 


\section{CONCLUSION}

The interactive learning multimedia is in excellent qualification and is declared feasible based on the results of the validity test of the experts. Thus, it is feasible to use in the learning process in the classroom. The use of interactive learning multimedia in the learning process is very effective in attracting students' interest in learning and making learning more interactive to improve student learning outcomes significantly.

\section{REFERENCES}

Abbas, J., \& Sagsan, M. (2020). Identification of Key Employability Attributes and Evaluation of University Graduates' Performance: Instrument Development and Validation. Higher Education, Skills and Work-Based Learning, 10(3), 449-466. https://doi.org/10.1108/HESWBL-06-2019-0075.

Abu-Eisheh, S. A., \& Ghanim, M. S. (2021). Improving Senior-Level Students' Performance in Traffic Systems Management using Multimedia Contents. Ain Shams Engineering Journal, хxхx. https://doi.org/10.1016/j.asej.2021.05.025.

Afriyanti, M., Suyatna, A., \& Viyanti. (2021). Design of E-Modules to Stimulate HOTS on Static Fluid Materials with the STEM Approach. Journal of Physics: Conference Series, 1788(1). https://doi.org/10.1088/1742-6596/1788/1/012032.

Agung, A. A. G. (2014). Metodologi Penelitian Pendidikan. Aditya Media.

Agustiwan, E. (2021). Pengembangan Media Pembelajaran Audio Visual untuk Meningkatkan Prestasi Belajar pada Mata Pelajaran PAI Siswa Kelas VII Di SMP Negeri 3 Pagar Alam. DIADIK: Jurnal Ilmiah Teknologi Pendidikan, 11 (2) 2021, 11(2), 5-24.

Alexander, C., Wyatt-Smith, C., \& Du Plessis, A. (2020). The Role of Motivations and Perceptions on the Retention of Inservice Teachers. Teaching and Teacher Education, 96, 103186. https://doi.org/10.1016/j.tate.2020.103186.

Antal, H., Bunnell, H. T., McCahan, S. M., Pennington, C., Wysocki, T., \& Blake, K. V. (2017). A Cognitive Approach for Design of a Multimedia Informed Consent Video and Website in Pediatric Research. Journal of Biomedical Informatics, 66, 248-258. https://doi.org/10.1016/j.jbi.2017.01.011.

Arif, \& Y. (2018). Pengantar Desain Pembelajaran. Pustaka Ma'Arif Press.

Astra, I. M., Raihanati, R., \& Mujayanah, N. (2020). Development of Electronic Module Using Creative Problem-Solving Model Equipped with Hots Problems on The Kinetic Theory of Gases Material. Jurnal Penelitian \& Pengembangan Pendidikan Fisika, 6(2), 181-194. https://doi.org/10.21009/1.06205.

Ayu, G., Mega, M., Sudhita, I. W. R., \& Suwatra, I. I. W. (2015). Pengembangan Multimedia Pembelajaran Interaktif Agama Hindu dengan Model ADDIE untuk Siswa Kelas VIII SMP. Jurnal Eductech Undiksha, 3(1), 1-11. https://doi.org/10.23887/jeu.v3i1.5869.

bin Abdul Samat, M. S., \& Abdul Aziz, A. (2020). The Effectiveness of Multimedia Learning in Enhancing Reading Comprehension Among Indigenous Pupils. Arab World English Journal, 11(2), 290-302. https://doi.org/10.24093/awej/vol11no2.20.

Bus, A. G., Neuman, S. B., \& Roskos, K. (2020). Screens, Apps, and Digital Books for Young Children: The Promise of Multimedia. AERA Open, 6(1), 233285842090149. https://doi.org/10.1177/2332858420901494.

Cahyadi, R. A. H. (2019). Pengembangan Bahan Ajar Berbasis ADDIE Model. Halaqa: Islamic Education Journal, 3(1), 35-42. https://doi.org/10.21070/halaqa.v3i1.2124.

Calista, D. H., \& Pujiriyanto. (2021). Efektivitas Multimedia Pembelajaran Interaktif PKK dalam Meningkatkan Kreativitas Berwirausaha Siswa SMK. Jurnal EPISTEMA, 2(1), 42-50.

Chen, E., \& Li, Z. (2011). On the Application of Multimedia Technology in Foreign Language Teaching and Learning in China's Colleges: Challenges, problems and implications. 2011 International Conference on Multimedia Technology, ICMT 2011, 595-597. https://doi.org/10.1109/ICMT.2011.6001903.

Chounta, I. A., Manske, S., \& Hoppe, H. U. (2017). Correction to: "From Making to Learning": introducing Dev Camps as an Educational Paradigm for Re-inventing Project-based Learning (International Journal of Educational Technology in Higher Education, 10.1186/s41239-017-0061-2). International Journal of Educational Technology in Higher Education, 14(1), 41239. https://doi.org/10.1186/s41239-017-0079-5.

Codreanu, E., Sommerhoff, D., Huber, S., Ufer, S., \& Seidel, T. (2020). Between Authenticity and Cognitive Demand: Finding a Balance in Designing a Video-Based Simulation in the Context of Mathematics Teacher Education. Teaching and Teacher Education, 95, 103146. https://doi.org/10.1016/j.tate.2020.103146.

Dede Mukti Herdiyanto, Sulton, H. P. (2020). Pengembangan Multimedia Pembelajaran Interaktif pada 
Materi Tema Tanah bagi Siswa Tunagrahita. JKTP Jurnal Kajian Teknologi Pendidikan, 3(1), 88-96. https://doi.org/10.17977/um038v3i12019p088.

Dumitrescu, C., Olteanu, R. L., Gorghiu, L. M., \& Gorghiu, G. (2014). Learning Chemistry in the Frame of Integrated Science Modules - Romanian Student's Perception. Procedia - Social and Behavioral Sciences, 116(September 2015), 2516-2520. https://doi.org/10.1016/j.sbspro.2014.01.603.

Fatqurhohman. (2021). Pelatihan Penggunaan Media Pembelajaran pada Guru SDN Sumberbulus 01 Kecamatan Ledokombo Jember. Mujtama' Jurnal Pengabdian Masyarakat, 1(2), 101-108. http://jurnal.unmuhjember.ac.id/index.php/Mujtama/article/view/5856.

Fauyan, M. (2019). Developing Interactive Multimedia Through Ispring on Indonesian Language Learning with The Insights of Islamic Values in Madrasah Ibtidaiyah. Al Ibtida: Jurnal Pendidikan Guru MI, 6(2), 177. https://doi.org/10.24235/al.ibtida.snj.v6i2.4173.

Febrita, I., \& Harni. (2020). Model Problem Based Learning dalam Pembelajaran Tematik Terpadu terhadap Berpikir Kritis Siswa di Kelas IV SD. Jurnal Pendidikan Tambusai, 4(2), 1619-1633. https://jptam.org/index.php/jptam/article/view/627.

Garbin, C., Zhu, X., \& Marques, O. (2020). Dropout vs. Batch Normalization: An Empirical Study of Their Impact to Deep Learning. Multimedia Tools and Applications, 79(19-20), 2777-12815. https://doi.org/10.1007/s11042-019-08453-9.

Ghory, S., \& Ghafory, H. (2021). The Impact of Modern Technology in the Teaching and Learning Process. International Journal of Innovative Research and Scientific Studies, 4(3), 168-173. https://doi.org/10.53894/ijirss.v4i3.73.

Graham, L. J., White, S. L. J., Cologon, K., \& Pianta, R. C. (2020). Do Teachers' Years of Experience Make a Difference in the Quality of Teaching? Teaching and Teacher Education, 96, 103190. https://doi.org/10.1016/j.tate.2020.103190.

Haddock, L., Cannon, K., \& Grey, E. (2020). A Comparative Analysis of Traditional and Online Counselor Training Program Delivery and Instruction. The Professional Counselor, 10(1), 92-105. https://doi.org/10.15241/lh.10.1.92.

Heo, M., \& Toomey, N. (2020). Learning with Multimedia: The Effects of Gender, Type of Multimedia Learning Resources, and Spatial Ability. Computers and Education, 146, 103747. https://doi.org/10.1016/j.compedu.2019.103747.

Hotimah, H. (2020). Penerapan Metode Pembelajaran Problem Based Learning dalam Meningkatkan Kemampuan Bercerita pada Siswa Sekolah Dasar. Jurnal Edukasi, 7(3), 5. https://doi.org/10.19184/jukasi.v7i3.21599.

Hussin, W. N. T. W., Harun, J., \& Shukor, N. A. (2018). Problem Based Learning to Enhance Students Critical Thinking Skill via Online Tools. Asian Social Science, 15(1), 14. https://doi.org/10.5539/ass.v15n1p14.

Imamah, N., \& Susanti, L. Y. (2021). Development of Sigil-Based Additives and Addictive Substances Teaching Chart for Junior High School Students: Alternative Learning Resources During a Pandemic. INSECTA: Integrative Science Education and Teaching Activity Journal, 2(1), 15-30. https://doi.org/10.21154/insecta.v2i1.2464.

Indah Septiani, A. nisa N. S., Septiani, I., Rejekiningsih, T., Triyanto, \& Rusnaini. (2020). Development of Interactive Multimedia Learning Courseware to Strengthen Students' Character. European Journal of Educational Research, 9(3), 1267-1279. https://doi.org/10.12973/eu-jer.9.3.1267.

Jogezai, N. A., Baloch, F. A., Jaffar, M., Shah, T., Khilji, G. K., \& Bashir, S. (2021). Teachers' Attitudes towards Social Media (SM) Use in Online Learning Amid the COVID-19 Pandemic: The Effects of SM Use by Teachers and Religious Scholars During Physical Distancing. Heliyon, 7(4). https://doi.org/10.1016/j.heliyon.2021.e06781.

Johansson, L. G., Grønvad, J. F., \& Budtz Pedersen, D. (2020). A matter of style: Research Production and Communication across Humanities Disciplines in Denmark in the Early-Twenty-First Century. Poetics, 83(May), 101473. https://doi.org/10.1016/j.poetic.2020.101473.

Kartika, Y., Wahyuni, R., Sinaga, B., \& Rajagukguk, J. (2019). Improving Math Creative Thinking Ability by using Math Adventure Educational Game as an Interactive Media. Journal of Physics: Conference Series, 1179(1), 1-6. https://doi.org/10.1088/1742-6596/1179/1/012078.

Kaso, N., Mariani, M., Ilham, D., Firman, F., Aswar, N., \& Iksan, M. (2021). The Principal's Leadership: How to Improve the Quality of Teaching and Learning Process in State Junior High School of Luwu. Jurnal Ad'ministrare, 8(1), 49. https://doi.org/10.26858/ja.v8i1.19126.

Kavanagh, S. S., Conrad, J., \& Dagogo-Jack, S. (2020). From Rote to Reasoned: Examining the Role of Pedagogical Reasoning in Practice-Based Teacher Education. Teaching and Teacher Education, 89, 102991. https://doi.org/10.1016/j.tate.2019.102991.

Khamparia, A., \& Pandey, B. (2017). Impact of Interactive multimedia in E-learning technologies: Role of 
multimedia in E-learning. Enhancing Academic Research With Knowledge Management Principles, April, 199-227. https://doi.org/10.4018/978-1-5225-2489-2.ch007.

Khamzawi, S., \& Wiyono, K. (2015). Pengembangan Multimedia Interaktif Berbasis Model Pembelajaran Problem Based Leaning Pada Mata Pelajaran Fisika Pokok Bahasan Fuida Dinamis Untuk SMA Kelas XI. Jurnal Inovasi Dan Pembelajaran Fisika, 2(1), 100-108. https://doi.org/10.36706/jipf.v2i1.2594.

Khan, F. M. A., \& Masood, M. (2015). The Effectiveness of an Interactive Multimedia Courseware with Cooperative Mastery Approach in Enhancing Higher Order Thinking Skills in Learning Cellular Respiration. Procedia - Social and Behavioral Sciences, 176, 977-984. https://doi.org/10.1016/j.sbspro.2015.01.567.

Kristiana, T. F., \& Radia, E. H. (2021). Meta Analisis Penerapan Model Problem Based Learning dalam Meningkatkan Hasil Belajar IPA Siswa Sekolah Dasar. Jurnal Basicedu, 5(2), 818-826. https://doi.org/10.31004/basicedu.v5i2.828.

Kristinawati, E., Susilo, H., \& Gofur, A. (2018). ICT Based-Problem Based Learning on Students' Cognitive Learning Outcomes. Jurnal Pendidikan Sains, 6(2), 38-42. https://doi.org/10.17977/jps.v6i2.11683.

Kumala, F. N., Setiawan, D. A., \& Shaleha, P. R. (2020). Contextual-Based Animal Encyclopedia: HOTS on Elementary School's Students. 2nd International Conference on Education and Social Science Research (ICESRE 2019) Contextual-Based, 417(Icesre 2019), 132-137. https://doi.org/10.2991/assehr.k.200318.025.

Kurniawan, F. Y., Siahaan, S. M., \& Hartono, H. (2020). Pengembangan Multimedia Interaktif Berbasis Adventure Game pada Materi Prinsip Animasi. Jurnal Inovasi Teknologi Pendidikan, 6(2), 183-195. https://doi.org/10.21831/jitp.v6i2.28488.

Lai, A. F., Chen, C. H., \& Lee, G. Y. (2019). An Augmented Reality-Based Learning Approach to Enhancing Students' Science Reading Performances from the Perspective of the Cognitive Load Theory. British Journal of Educational Technology, 50(1), 232-247. https://doi.org/10.1111/bjet.12716.

Lauc, T., Jagodić, G. K., \& Bistrović, J. (2020). Effects of Multimedia Instructional Message on Motivation and Academic Performance of Elementary School Students in Croatia. International Journal of Instruction, 13(4), 491-508. https://doi.org/10.29333/iji.2020.13431a.

Lee, T. T., \& Osman, K. (2012). Interactive Multimedia Module in the Learning of Electrochemistry: Effects on Students' Understanding and Motivation. Procedia - Social and Behavioral Sciences, 46. https://doi.org/10.1016/j.sbspro.2012.05.295.

Lestari, D. (2019). Pengaruh Model Pembelajaran Problem Based Learning terhadap Hasil Belajar Ipa Siswa Ditinjau dari Kemampuan Dasar Matematika. Belantika Pendidikan, 1(2), 44-55. https://doi.org/10.47213/bp.v1i2.21.

Liang, Y., Zheng, T., \& Wang, M. (2011). English Audio-Visual Teaching Mode and Its Teaching Environment Construction - Henan Institute of Science and Technology as the Example. 2011 International Conference on Multimedia Technology, 3050-3053. https://doi.org/10.1109/ICMT.2011.6001924.

Lynch, M., Sage, T., Hitchcock, L. I., \& Sage, M. (2021). A Heutagogical Approach for the Assessment of Internet Communication Technology (ICT) Assignments in Higher Education. International Journal of Educational Technology in Higher Education, 18(1). https://doi.org/10.1186/s41239-02100290-x.

Marnita, \& Ernawati. (2017). The Use of Interactive Multimedia (Macromedia Flash) to Increase Creative Thinking Ability of Students in Basic Physics Subject. Jurnal Pendidikan Fisika Indonesia, 13(2), 7178. https://doi.org/10.15294/jpfi.v13i2.10152.

Müller, F. A., \& Wulf, T. (2020). Technology-Supported Management Education: A Systematic Review of Antecedents of Learning Effectiveness. International Journal of Educational Technology in Higher Education, 17(1). https://doi.org/10.1186/s41239-020-00226-x.

Ngalimun. (2016). Strategi dan Model Pembelajaran. Aswaja Pressindo.

Ngurah, G., Nugraha, S., Tegeh, I. M., \& Sudarma, I. K. (2019). Pengembangan Multimedia Interaktif Matematika Berorientasi Kearifan Lokal Kelas 3 Sekolah Dasar Negeri 1 Paket Agung. Jurnal Edutech, 7(1), 12-22. https://ejournal.undiksha.ac.id/index.php/JEU/article/view/19972.

Nurtanto, M., Fawaid, M., \& Sofyan, H. (2020). Problem Based Learning (PBL) in Industry 4.0: Improving Learning Quality through Character-Based Literacy Learning and Life Career Skill (LL-LCS). Journal of Physics: Conference Series, 1573(1), 0-10. https://doi.org/10.1088/1742$6596 / 1573 / 1 / 012006$

Oh, E. (2019). Research on the Effective of Peer Instruction and Students' Involvement. Asia-Pacific of Multimedia Services Convergent with Art Humanities, and Sociology, 9, 199-208. https://doi.org/10.35873/ajmahs. 
Prasetyo, G., Hidayatullah, M. F., Akhyar, M., Wiranto, \& Perdana, R. (2020). Strengthening Students' Character through Multimedia Learning in Primary Schools Education: Systematic Literatur. Humanities \& Social Sciences Reviews, 8(3), 268-277. https://doi.org/10.18510/hssr.2020.8328.

Purwanita, Y., Riyanto, Y., \& Suyanto, T. (2019). The Influence of Multimedia Assisted Inquiry Learning Methods on My Heroes Theme of Critical Thinking Skills and Learning Outcomes of Class IV Students ofElementary School. International Journal of Scientific and Research Publications (IJSRP), 9(7), p9169. https://doi.org/10.29322/ijsrp.9.07.2019.p9169.

Ran, W., \& Jinglu, L. (2020). The Design and Development of Digital Books for E-learning. 2020 4th International Conference on Artificial Intelligence and Virtual Reality, 51-55. https://doi.org/10.1145/3439133.3439140.

Rubini, B., Permanasari, A., \& Yuningsih, W. (2018). Learning Multimedia Based on Science Literacy on the Lightning Theme. Jurnal Penelitian Dan Pembelajaran IPA, 4(2), 89-104. https://doi.org/10.30870/jppi.v4i2.3926.

Ružičić, V. (2021). Development of Methodology Successful Realization of the Teaching Process. Узданица, 18(1), 231-244. https://doi.org/10.46793/uzdanica18.1.231r.

Samsudin, A., Kelana, J. B., \& Muftianti, A. (2019). Utilization of Internet-Based Learning Media in Enhancing Science Literacy Capabilities of Pgsd Students. PrimaryEdu - Journal of Primary Education, 3(2), 91. https://doi.org/10.22460/pej.v3i2.1284.

Sanjaya, W. (2015). Perencanaan dan Desain Sistem Pembelajaran. Kencana Prenada Media Grup.

Septia, T., Prahmana, R. C. I., Pebrianto, \& Wahyu, R. (2018). Improving Students Spatial Reasoning with Course Lab. Journal on Mathematics Education, 9(2), 327-336. https://doi.org/10.22342/jme.9.2.3462.327-336.

Shea, P., Hayes, S., Uzuner Smith, S., Vickers, J., Bidjerano, T., Gozza-Cohen, M., Jian, S. B., Pickett, A. M., Wilde, J., \& Tseng, C. H. (2013). Online Learner Self-Regulation: Learning Presence Viewed through Quantitative Content- and Social Network Analysis. International Review of Research in Open and Distance Learning, 14(3), 427-461. https://doi.org/10.19173/irrodl.v14i3.1466.

Simamora, R. M. (2020). The Challenges of Online Learning during the COVID-19 Pandemic: An Essay Analysis of Performing Arts Education Students. Studies in Learning and Teaching, 1(2), 86-103. https://doi.org/10.46627/silet.v1i2.38.

Suartama, I. K. (2016). Evaluasi dan Kriteria Kualitas Multimedia Pembelajaran. Universitas Pendidikan Ganesha.

Suryawati, E., \& Osman, K. (2018). Contextual learning: Innovative Approach towards the Development of Students' Scientific Attitude and Natural Science Performance. Eurasia Journal of Mathematics, Science and Technology Education, 14(1), 61-76. https://doi.org/10.12973/ejmste/79329.

PSyauqi, K., Munadi, S., \& Triyono, M. B. (2020). Students' Perceptions toward Vocational Education on Online Learning during the COVID-19 Pandemic. International Journal of Evaluation and Research in Education (IJERE), 9(4), 881. https://doi.org/10.11591/ijere.v9i4.20766.

Utama, C., Kentjananingsih, S., \& Rahayu, Y. S. (2014). Penerapan Media Pembelajaran Biologi SMA dengan Menggunakan Model Direct Instruction untuk Meningkatkan Hasil Belajar Siswa. Jurnal Pena Sains, 1(1), 29-39. https://doi.org/10.21107/jps.v1i1.1325.

Weng, C., Otanga, S., Weng, A., \& Cox, J. (2018). Effects of Interactivity in E-Textbooks on 7th Graders Science Learning and Cognitive Load. Computers \& Education, 120, 172-184. https://doi.org/10.1016/j.compedu.2018.02.008.

Weng, S. S., \& Chen, H. C. (2020). Exploring the Role of Deep Learning Technology in the Sustainable Development of the Music Production Industry. Sustainability (Switzerland), 12(2), 1-20. https://doi.org/10.3390/su12020625.

Yuzulia, I. (2021). The Challenges of Online Learning during Pandemic: Students' Voice. Wanastra: Jurnal Bahasa Dan Sastra, 13(1), 08-12. https://doi.org/10.31294/w.v13i1.9759.

Zhang, Y., Ghandour, A., \& Shestak, V. (2020). Using Learning Analytics to Predict Students Performance in Moodle LMS. International Journal of Emerging Technologies in Learning. https://doi.org/10.3991/ijet.v15i20.15915. 